\title{
OPTIMALISASI PERAN KADER DALAM BUDI DAYA TOGA WILAYAH KERJA PUSKESMAS SUNGAI RANGIT
}

\author{
Fakhruddin $^{1}$ Nur Aini Hidayah Khasanah ${ }^{2}$ Ni Wayan Rahayu Ningtyas ${ }^{3}$ \\ ${ }^{123}$ STIKes Borneo Cendekia Medika Pangkalan Bun \\ ${ }^{1}$ Email : dedekfakhruddin@gmail.com
}

\begin{abstract}
ABSTRAK
Wilayah sungai rangit terletak di pinggir Kabupaten Kotawaringin Barat, lokasinya berada agak jauh dari pusat kota Pangkalanbun, sehingga wilayah sungai rangit ini dapat dikategorikan masuk dalam wilayah pedesaan. Wilayah sungai rangit cukup luas dan tidak terlalu padat, sehingga masih banyak pekarangan luas di wilayah tersebut. Dari kegiatan ini diketahui bahwa para kader dan masyarakat ternyata masih belum memahami tentang Tanya. Sebagian kader dan hampir seluruh masyarakat sekitar puskesmas belum mengerti dan paham tentang Tanya dengan metode demontrasi. Setelah kegiatan ini terlaksana, para kader dan masyarakat menjadi mengerti dan paham tentang apa itu Tanya dengan metode demonstrasi. Hal itu ditandai dengan mampu menjawab pertanyaan tentang Tanya dengan metode demontrasi.
\end{abstract}

Kata kunci : metode demontrasi

\section{OPTIMALIZATION OF CADRES IN CULTIVATION OF TOGA WORKING AREA OF RANGIT RIVER HEALTH CENTER}

\begin{abstract}
The Rangit River area is located at the edge of West Kotawarcinta Regency, located a bit far from the city center of Pangkalanbun, so that this Rangit River area can be categorized into a rural area. The area of the Rangit River is wide enough and not too dense, so there are many large yards in the area. From this activity, it is known that cadres and people are still not understanding about Tanya. Some cadres and almost all communities around the puskesmas have not understood and understand about Tanya with a demonstration method. After this activity, the cadres and the community become familiar and understand what is asked by the demonstration method. It was characterized by being able to answer questions about Tanya with a demonstration method.
\end{abstract}

Keywords: Demonstration method

\section{PENDAHULUAN}

Wilayah sungai rangit terletak di pinggir Kabupaten Kotawaringin Barat, lokasinya berada agak jauh dari pusat kota Pangkalanbun, sehingga wilayah sungai rangit ini dapat dikategorikan masuk dalam wilayah pedesaan. Wilayah sungai rangit cukup luas dan tidak terlalu padat, 
sehingga masih banyak pekarangan luas di wilayah tersebut. Warga masyarakat di daerah sungai rangit biasa memanfaatkan pekarangan yang berada di sekitar rumahnya untuk ditanami berbagai jenis tanaman. Dari berbagai macam tumbuhan yang hidup di pekarangan warga, banyak diantaranya yang merupakan tumbuhan yang dapat dipergunakan sebagai tanaman obat tradisional. Beberapa warga, kadang menggunakan tanaman-tanaman tersebut untuk mengobati keluhan kesehatan yang dirasakan, namun pemanfaatannya belum terlalu optimal karena selama ini penggunaan tanaman obat tradisional itu hanya didasarkan pada pendapat teman atau tetangga.Penggunaan obat tradisional yang tidak sesuai denganaturan, dikhawatirkan dapat mengurangi khasiat obat itu sendiri. Jika penggunaannya terlalu banyak, dikhawatirkan juga akan memberikan efek toksik yang akan membayakan bagi masyarakat.

Kader kesehatan adalah tenaga yang berasal dari masyarakat yang dipilih oleh masyarakat dan bekerja bersama untuk masyarakat secara sukarela (Mantra, 1983). Kader kesehatan masyarakat adalah laki-laki atau wanita yang dipilih oleh masyarakat dan dilatih untuk menanggani masalah-masalah kesehatan perseorangan maupun masyarakat setra untuk bekerja dalam hubungan yang amat dekat dengan tempat- tempat pemberian pelayanan kesehatan (WHO, 1995). Kader sebagai warga masyarakat setempat yang dipilih dan ditinjau oleh masyarakat dan dapat bekerja secara sukarela. Kader secara sukarela bersedia berperan melaksanakan dan mengelola kegiatan keluarga berencana di desa (Karwati, dkk, 2009).

Tanaman Obat Keluarga (TOGA) pada hakekatnya adalah tanaman berkhasiat yang ditanam di lahan pekarangan yang dikelola oleh keluarga. Ditanam dalam rangka memenuhi keperluan keluarga akan obat-obatan tradisional yang dapat dibuat sendiri.

Obat adalah semua sediaan untuk penggunaan manusia dengan tujuan memulihkan atau mengetahui kondisi fisiologis atau patologis untuk kebaikan pengguna sediaan (Dirjen POM, 2012).Penggunaan Obat Rasional adalah apabila pasien menerima pengobatan sesuai dengan kebutuhan klinisnya, dalam dosis yang sesuai dengan kebutuhan, dalam periode waktu yang sesuai dan dengan biaya yang terjangkau oleh dirinya dan kebanyakan masyarakat (WH0, 2014).Pengetahuan tentang obat yang benar merupakan suatu hal yang penting. Obat merupakan komponen penting dalam pelayanan kesehatan karena intervensi obat diperlukan dalam sebagian besar upaya kesehatan baik upaya preventif, kuratif, promotif dan rehabilitatif. Penting untuk disadari bahwa obat merupakan substansi yang tidak hanya dapat memberikan manfaat, tetapi juga bahaya. Obat hanya akan memberikan manfaat jika digunakan dalam cara pakai yang benar dan jika dengan benar pula. Dengan pengetahuan yang benar, masyarakat akan dapat memperoleh manfaat maksimal dari obat dan dapat meminimalkan segala hal yang tidak diinginkan yang dapat terjadi akibat pemakaian suatu obat. 


\section{METODE PENELITIAN}

Metode yang kami gunakan dalam penyuluhan ini adalah dengan metode ceramah dan tanya jawab yang berkaitan tentang pembudidayaan toga dan manfaatnya (bagaimana budidaya yang baik, kandungannya, berapa dosisnya, bagaimana cara menggunakannya, dan apa efek sampingnya) dengan metode demontrasi para kader dan masyarakat.

\section{HASIL DAN PEMBAHASAN}

Kegiatan ini berupa penyuluhan mengenai optimalisasi peran kader dalam budi daya toga diwilayah kerja puskesmas sungai rangit. Penyuluhan dilaksanakan di Puskesmas Sungai Rangit. Tujuan kegiatan ini adalah untuk meningkatkan pengetahuan para kader dalam membudidayakan toga sehingga akan meningkatkan pengetahuan para kader dan masyarakat. Penyuluhan ini langsung disampaikan kepada para kader dan masyarakat oleh dosen Pengmas. Materi yang disampaikan mengenai pengenalan pembudidayaan yang baik, tentang Tanya (apa nama toga dan kandungannya, apa kegunaannya, berapa dosisnya, dan apa efek sampingnya) dengan metode demontrasi serta mengajak para kader melihat lansung toga.

Dari kegiatan ini diketahui bahwa para kader dan masyarakat ternyata masih belum memahami tentang Tanya. Sebagian kader dan hampir seluruh masyarakat sekitar puskesmas belum mengerti dan paham tentang Tanya dengan metode demontrasi. Setelah kegiatan ini terlaksana, para kader dan masyarakat menjadi mengerti dan paham tentang apa itu Tanya dengan metode demonstrasi. Hal itu ditandai dengan mampu menjawab pertanyaan tentang Tanya dengan metode demontrasi.

\section{KESIMPULAN DAN SARAN}

\section{Kesimpulan}

Setelah kegiatan program pengabdian kepada para kader dan masyarakat sekitar Puskesmas Sungai Rangit ini terlaksana, para kader dan masyarakat menjadi mengerti dan paham tentang Tanya dengan metode demonstrasi.

Penting untuk disadari bahwa toga merupakan substansi yang tidak hanya dapat memberikan manfaat, tetapi juga bahaya. Toga hanya akan memberikan manfaat jika digunakan dalam cara pakai yang benar dan jika dengan benar pula. Dengan pengetahuan yang benar, para kader dan masyarakat akan dapat memperoleh manfaat maksimal dari toga dan dapat meminimalkan segala hal yang tidak diinginkan yang dapat terjadi akibat pemakaian toga dengan tidak baik.

\section{Saran}

Dengan adanya kegiatan penyuluhan pengabdian masyarakat ini seharusnya masyarakat dapat lebih dini mengenal tentang budidaya dan manfaat toga dan bagaimana cara penggunana yang baik dan benar sehingga tidak menimbulkan resiko yang tidak diinginkan.

\section{DAFTAR PUSTAKA}

BPOM. (2012). Pengetahuan Tentang Obat: Perlunya Pendekatan dari Perspektif Masyarakat.,Majalah Info POM Vol. 9 No. 4

WHO. Maternal Mortality: World Health Organization; 2014. 